\title{
THE GENERA OF NORTH AMERICAN MELANOPLI.
}

\author{
By Samuel H. Scudder.
}

Presented January 13, 1897.

In an extended paper upon the Melanopli (Pezotettiges Brunn.) to be published by the U. S. National Museum, I have treated this group monographically, with full descriptions of each genus and species, accompanied by keys for their determination. As some time must elapse before the final publication of this work, which was completed in December, 1895, and will be abundantly illustrated, I present herewith, by permission of the Museum, the table therein given for the determination of the genera of Melanopli, appending a few remarks to show how the species already known are distributed among them. The fuller paper will contain the complete revision, with full synonymy.

\section{Table of the Genera of North American Melanopli.}

$A^{1}$. Lateral margins of subgenital plate (last ventral segment) of male, as seen laterally, straight throughout or very slightly convex, never at all abruptly ampliate at the base.

$b^{1}$. Body exceptionally slender; mesosternal lobes subattingent in both sexes; prozona three times as long as metazona . . Gymnoscirtetes. $b^{2}$. Body not exceptionally slender; mesosternal lobes in both sexes so widely separated that the interspace between them is at most twice as long as broad; prozona not more than twice as long as metazona.

$c^{1}$. Interspace between mesosternal lobes of female decidedly transverse, sometimes twice as broad as long; of male sometimes transverse, sometimes quadrate or subquadrate ; tegmina lobiform, linear, or wanting.

$d^{1}$. Interspace between mesosternal lobes of male decidedly transverse, as broad as or broader than the lobes; pronotum without lateral carinæ; tegmina ovate or wanting . . . . Netrosoma. 
$d^{2}$. Interspace between mesosternal lobes of male quadrate or subquadrate, or, if feebly transverse (as in Paradichroplus), not so broad as the lobes, and then the pronotum furnished with lateral carinæ; tegmina ovate or linear.

$e^{1}$. Subgenital plate of male pyramidal, pointed, a slight tubercle extending beyond its posterior margin, but the margin extending well beyond the apex of the supraanal plate.

Paradichroplus.

$e^{2}$. Subgenital plate of male more or less conically protuberant apically, but its interior apical margin not surpassing or barely surpassing the apex of the supraanal plate.

$f^{1}$. Apical tubercle of subgenital plate small, extending but a short distance beyond the supraanal plate; cerci of male abruptly narrowed before the middle by excision of the inferior margin, the apical half narrow; lateral carinæ of pronotum wholly wanting . . . . . Phadrotettix.

$f^{2}$. Nearly the whole subgenital plate forming a blunt conical tubercle projecting some distance beyond the supraanal plate ; cerci of male forming broad, apically decurved, subfalcate laminæ; lateral carinæ of pronotum more or less distinct . . . . . . . . . . . . . . . Conalcaa.

$c^{2}$. Interspace between mesosternal lobes of female generally longer than broad, sometimes quadrate, rarely feebly transverse; * of male never at all transverse (except feebly in Sinaloa and Cephalotettix); tegmina variable.

$d^{1}$. Tegmina never fully developed, rarely as long as the pronotum, lateral and ovate or linear, or wholly wanting; hind margin of pronotum distinctly truncate; fore and middle femora of male (except in Phaulotettix) distinctly more gibbous than in the female.

$e^{1}$. Furcula of male wanting, or forming a pair of brief lobes, at most no longer than broad.

$f^{1}$. Last dorsal segment of male furnished mesially with a pair of slightly protuberant rounded lobes; cerci of male compressed laminate, beyond the slightly narrowing basal portion equal or subequal, the tip curved downward or inferiorly angulate at apex.

\footnotetext{
* Cephalotettix, in which the female is unknown, is placed in this division.
} 
$g^{1}$. Prosternal spine erect; interspace between mesosternal lobes of male nearly twice as long as broad; fore and middle femora of male noticeably gibbous; subgenital plate of male terminating in a large conical tubercle.

Barytettix.

$g^{2}$. Prosternal spine retrorse; interspace between mesosternal lobes of male only a little longer than broad; fore and middle femora of male only slightly gibbous ; subgenital plate of male with no apical tubercle. . Phaulotettix.

$f^{2}$. Last dorsal segment of male entirely without projecting lobes or furcula in any form, unless as exceptionally broad and short sessile plates; cerci of male (except in Cephalotettix) apically acuminate or curved upwards.

$g^{1}$. Head large, and eyes, at least in male, large and very prominent, the breadth of the head distinctly exceeding the greatest width of the pronotum; interspace between mesosternal lobes of male slightly transverse.

Cephalotettix.

$g^{2}$. Head normal and eyes not very prominent even in the male, so that the breadth of the head does not exceed the greatest width of the pronotum; interspace between mesosternal lobes of male distinctly longer than broad.

$h^{1}$. Tegmina lobiform; subgenital plate of male protruding beyond the tip of the supraanal plate by less than half the length of the latter; cerci of male compressed, subequal, the tip broad . . . Rhabdotettix.

$h^{2}$. Tegmina linear; subgenital plate of male protruding beyond the tip of the supraanal plate by much more than half the length of the latter; cerci of male tapering from the base, the tip acuminate . . Cyclocercus.

$e^{2}$. Furcula of male consisting of a pair of parallel, attingent, cylindrical processes, generally at least twice as long as broad.

$f^{1}$. Tegmina lobiform; interspace between mesosternal lobes of male slightly transverse; cerci of male forming compressed subequal laminæ . . . . . . . . . . . Sinaloa. $f^{2}$. Tegmina wanting; interspace between mesosternal lobes of male longer than broad; cerci of male styliform, conical.

Paraidemona. 
$d^{2}$. Tegmina fully developed or abbreviate, never much if any shorter than the pronotum; hind margin of pronotum distinctly angulate; fore and middle femora scarcely more gibbous in the male than in the female (except in some species of Campylacantha).

$e^{1}$. Tegmina fully developed; disk of pronotum nearly flat, the lateral lobes nearly at right angles to it, the posterior margin rectangulate or subrectangulate; prosternal spine quadrate, appressed, broadly truncate . . . . . . . . Aidemona. $e^{2}$. Tegmina abbreviate; disk of pronotum tectiform, the posterior margin obtusangulate; prosternal spine more or less conical and acuminate.

$f^{1}$. Head not prominent, the summit very slightly arched longitudinally; prosternal spine erect; furcula of male composed of projecting cylindrical fingers; surface of body very feebly pilose . . . . . . . . . . Hypochlora.

$f^{2}$. Head prominent, the summit strongly arched longitudinally; prosternal spine more or less retrorse; furcula of male reduced to slight scarcely projecting lobes; surface of the body rather densely pilose . . . Campylacantha.

$A^{2}$. Lateral margins of subgenital plate of male suddenly ampliate to a considerable degree at the base; or if not to a considerable degree, then the entire margin rather strongly convex or sinuate.

$b^{1}$. Subgenital plate of male furnished with a distinct subapical tubercle (i. e., one in which the apical margin does not pass through and form a part of the summit of the tubercle, but where it is distinctly separated from the summit), but not otherwise tumescent (see note under $A^{2} b^{2}$ ).

$c^{1}$. Median carina of pronotum well developed and equally developed throughout, accompanied on the front of the prozona by distinct lateral carinæ; prosternal spine sharply acuminate; tubercle of subgenital plate directed wholly backward, occupying the middle of the terminal portion of the plate; furcula distinctly developed.

Eotettix.

$c^{2}$. Median carina of pronotum feebly developed and generally much more feebly on the prozona than on the metazona, accompanied by no lateral carinæ whatever; prosternal spine bluntly acuminate; tubercle of subgenital plate directed upward, or upward and backward, occupying the upper extremity of the terminal portion of the plate. 
$d^{1}$. Body relatively slender and compressed, not much enlarged at the metathorax, particularly in the male; disk of the pronotum tectiform, * the prozona not distinguished from the metazona either by its plane or by any lack of a median carina, which latter is generally marked in color; pronotum fully half as long again as broad; hind femora long and slender; apical tubercle of male abdomen prominent; furcula present as distinctly projecting lobes; terminal segments of female abdomen not abbreviated, the ovipositor fully exserted . . . . . . . . . Hesperotettix. $d^{2}$. Body relatively short and stout, considerably enlarged at the metathorax eren in the male; disk of pronotum generally convex transversely; the prozona slightly and independently tumid with no median carina, thus distinguishing it from the metazona; $\dagger$ hind femora relatively short and stout; apical tubercle of male abdomen not very prominent; furcula scarcely or not apparent; terminal segments of female abdomen abbreviated, the ovipositor only partially exserted . . . . . . . . . Eoloplus.

$b^{2}$. Subgenital plate of male with no distinct subapical tubercle, but often apically prolonged or tumescent.

$c^{1}$. Meso- and metastethium together, in both sexes, no longer or scarcely longer than broad; metastethium narrowing but little posteriorly, so that the portion behind the metasternal lobes is but little narrower than the rest, rarely (in the male) less than three fourths its width; cerci of male very simple, subconical, straight; ovipositor half concealed . . . . . . . . . Bradynotes. $c^{2}$. Meso- and metastethium together, at least in the male and nearly always in both sexes, distinctly longer than the width of the metastethium; the latter rapidly narrowing posteriorly, so that the portion behind the metasternal lobes is not, or is hardly more than, one half the greatest width of the metastethium; cerci of male variable; ovipositor generally fully exserted.

$d^{1}$. Interspace between mesosternal lobes of male distinctly transverse. $\S$ as broad or nearly as broad as the lobes themselves; of

* This feature is not so apparent in some species as in others.

$\dagger$ This feature is less marked in some species than in others.

$\ddagger$ There is a minute subapical tubercle in some species of the flabellifer group of Melanoplus, but in these the male cerci are exceptionally broad; while in the species of the alternate category $\left(A^{2} b^{1}\right)$ they are very siender and tapering.

$\S$ In many cases the interspace is truncato-cuneiform or broadly clepsydral, in which cases the breadth is to be measured in the middle. 
the female distinctly or strongly transverse, fully as broad as or (and generally) broader than the lobes; metasternal lobes of male generally distinctly distant, occasionally approximate; of the female generally more distant, the interspace in the latter generally as wide as or wider than the frontal costa; tegmina typically abbreviate.

$e^{1}$. Face almost vertical; eyes small but prominent and widely distant; pronotum constricted in the middle, with deeply impressed transverse sulci, and the lateral lobes not obliquely . truncate apically in front; distinct lateral carinæ.

Dendrotettix.

$e^{2}$. Face a little oblique; eyes rather large, not very prominent and not very distant; pronotum not, or but feebly, constricted in the middle, with generally feebly impressed transverse sulci, and the lateral lobes obliquely truncate apically on the anterior section . . . . . . . . . . . . . . . Podisma.

$\left[f^{1}\right.$. Pronotum of subequal width, the sides nearly parallel; subgenital plate of male normal . . . . Podisma s.s.

$f^{2}$. Pronotum enlarging posteriorly, conspicuously in the female; subgenital plate of male exceptionally expanded, laterally tumid, and elevated premarginally . Eupodisma.]

$d^{2}$. Interspace between mesosternal lobes generally longer or much longer than broad in the male, almost never (cf. Mel. montanus Thom.) in the least broader than long even when the sides of the interspace are posteriorly divergent; generally quadrate in the female, but more variable than in the other sex, sometimes as narrow as there, more often subtransverse, occasionally in some brachypterous forms (as in Mel. artemisia Brun., Mel. militaris Scudd., Mel. altitudinum Scudd., and Asemoplus) distinctly transverse; in both sexes always distinctly, generally much, narrower than the lobes (except in the females of the cases just cited, where they are barely narrower); metasternal lobes of male generally attingent or subattingent, rarely only approximate; of the female less distant than in the alternate category $\left(A^{2} b^{2} c^{1} d^{1}\right)$, generally approximate or subapproximate, the interspace generally narrower than the frontal costa; typically the tegmina are completely developed.

$e^{1}$. Face almost vertical or a little oblique, its angle with the fastigium rarely less than $75^{\circ}$; eyes rounded oval, never more generally less than half as long again as broad; portion of 
metasternum lying behind the lobes transverse, more than twice as broad as long; tegmina normally present.

$f^{1}$. Tegmina always present ; sides of first abdominal segment with a distinct tympanum.

$g^{1}$. Fastigium of vertex plane or convex; eyes separated widely, the space between them twice as broad as the frontal costa; pronotum furnished with distinct percurrent lateral carinæ; tegmina abbreviate; cerci apically acuminate . . . . . . . . Paratylotropidia.

$g^{2}$. Fastigium of vertex more or less depressed or with elevated lateral margins; eyes separated narrowly, at most but little further apart than the width of the frontal costa; pronotum with indistinct* or no lateral carinæ; tegmina fully developed or abbreviate; cerci variable, rarely acuminate apically.

$h^{1}$. Inferior genicular lobe of hind femora with at least a darker basal spot or transverse band; cerci of male variable, often enlarging apically.

$i^{1}$. Dorsum of pronotum rarely or never twice as long as the average breadth, generally only half as long again, even in the male, generally constricted more or less in the middle; antennæ even when longest (as in Mel. packardii Scudd., Mel. nitidus Scudd.) no longer than the hind femora, and only twice as long as the pronotum alone; face rarely as declivent as in Paroxya; prozona usually a half longer than the metazona.

$j^{1}$. Head not large in proportion to pronotum, nor prominent, but little longer than the prozona, unless (as in Mel. spretus Uhl.e.g.) the latter is distinctly transverse; pronotum in no way subsellate, nor flaring in front; tegmina, when fully developed, narrow, rarely (Mel. fasciatus Barnst., $\dagger$ Mel. dawsoni Scudd.,) rather broad, but then very distinctly tapering, more or less tapering in distal half, at

* In a few species they are tolerably distinct.

$\dagger$ In form of tegmina and sparseness of neuration, the macropterous form of this species is the Melanoplus most nearly allied to Phœtaliotes, and like it, the species is dimorphic as to tegmina. 
a distance from the apex equal to the breadth of the tegmina distinctly narrower than the metazona, the intercalaries and cross-veins of the discoidal area relatively numerous, at least in the apical fourth and usually throughout, the venation in general sharp and clearly defined, the area intercalata distinctly defined by the adjustment of the veins at its distal extremity, the humeral vein straight and apically arcuate, nearly always terminating either on the apical margin or but a short distance before it, running for some distance almost exactly parallel to the costal margin or merging insensibly into it; cerci of male very variable, very rarely ( $\mathrm{Mel}$. flabellatus Scudd., Mel. puer Scudd.) styliform, and then the subgenital plate is either exceptionally broad or only moderately narrow, and the apical margin elevated.

Melanoplus.

$j^{2}$. Head large in proportion to pronotum, nearly half as long again as the long prozona; pronotum faintly subsellate, feebly flaring in front to receive the head; tegmina, when fully developed, broad and subequal, hardly tapering in the distal half, at a distance from the apex equal to the breadth of the tegmina as broad as the metazona, the intercalaries and cross-veins of the discoidal area everywhere few, the venation in general loose and ill defined, the area intercalata not distinctly marked by the adjustment of the veins at its distal extremity, the humeral vein broadly sinuous, terminating on the costal margin at least as far before the apex as the breadth of the tegmina, nowhere running closely parallel to that margin nor merging into it; cerci of male styliform, the subgenital plate very narrow, the margin not apically elevated . . . . . . . . Photaliotes.

$i^{2}$. Dorsum of pronotum twice as long as average breadth, at least in the male, with no median constriction; antenuæ, at least in the male, generally longer than the hind femora and much more than 
twice as long as the pronotum, generally twice as long as head and pronotum together; face more declivent than in Melanoplus; prozona only about a third longer than the metazona . . Paroxya. $h^{2}$. Inferior genicular lobe of hind femora wholly pallid, with no dark basal spot or transverse band; cerci of male conical or subconical or basally bullate, always apically pointed.

$i^{1}$. Subgenital plate of male terminating in a pronounced tubercle; prosternal spine slender.

Precilotettix.

$i^{2}$. Subgenital plate of male, even when apically angulate, not furnished with an apical tubercle; prosternal spine stout.

$j^{1}$. Relatively heavy bodied; dorsal disk of the prozona tumid independently of the metazona; pronotum distinctly angulate or convex behind; the portion of the metasternum lying behind the lobes laterally extended, reaching to the coxæ; tegmina fully developed or abbreviate but overlapping, with many longitudinal veins; cerci of male very stout and bullate on basal half or more; abdomen of female bluntly rounded apically, the posterior segments much abbreviated; ovipositor but slightly exserted . . . . Edaleonotus. $j^{2}$. Relatively slender bodied; dorsal disk of prozona not tumid independently of the metazona; pronotum truncate posteriorly; portion of metasternum lying behind the lobes laterally abbreviated, much narrower than the width between coxæ; tegmina linear, lateral, distant, with only a few longitudinal veins; abdomen of female tapering regularly to a pointed tip; ovipositor normally exserted . . . . . . . . . . Asemoplus.

$f^{2}$. Tegmina wanting; sides of first abdominal segment with no tympanum . . . . . . . . . . . Philocleon. $e^{2}$. Face rather strongly oblique, the angle it makes with the fastigium varying about from $55^{\circ}$ to $67^{\circ}$; eyes elongate, almost or quite twice as long as broad; portion of metasternum lying 
behind the lobes subtriangular, not greatly broader than long; tegmina linear and lateral or absent . . . . Aptenopedes.

Gymnoscirtetes Bruner MS. contains a single undescribed species from Florida, of a somewhat anomalous character.

Netrosoma gen. nov. is based on two species from Mexico, both of them new.

Paradichroplus Brunner is represented in North America by two species from Mexico and Central America, mexicanus Brunn., and varicolor Stål.

Phædrotettix gen. nov. has but a single and undescribed species, which comes from Mexico and southern Texas.

Conalcæa gen. nov. has three species, all of them new; they occur in Mexico and southwestern New Mexico.

Barytettix gen. nov. is known only from Lower California, where it is represented by two undescribed species.

Phaulotettix gen. nov. contains a single and undescribed species from Mexico.

Cephalotettix gen. nov. is also monotypic and the species is new and from Mexico.

Rhabdotettix gen. nov. contains three species from Texas and Mexico, pilosus Stål and two undescribed forms.

Cyclocercus gen. nov. also contains three species found in northern Mexico and southern Texas, all of them new.

Sinaloa gen. nov. is founded upon a single, as yet unpublished Mexican species.

Paraidemona Brunner is found in Texas and northern Mexico, and is restricted to punctata Stål and a new species, the other species referred to it by Brunner being placed elsewhere.

Aidemona Brunner is confined to azteca Sauss., found in Mexico.

Hypochlora Brunner was originally founded on three species, but is here restricted to only one of them, alba Dodge, found on the eastern margin of the Rocky Mts.

Campylacantha gen. nov. is composed of four species found in the western United States east of the Rocky Mts., from Nebraska to Texas, and in Durango, Mexico. The species are acutipennis Scudd., olivacea Scudd., vivax Scudd., and one undescribed species.

Eotettix gen. nov. is founded on a single undescribed species from Florida. 
Hesperotettix Scudder is found across the continent, but only a single species, brevipennis Thom., is known east of the Great Plains, and that has been found only on or near the Atlantic border. The other species are viridis Thom., pacificus Brun. (undescr.), speciosus Scudd., and four new species, including two which have often been confounded with one of the foregoing.

Aoloplus gen. nov. is confined to the western half of the United States from the Yellowstone to the Mexican border. I have seen no species from further east than western Kansas and Nebraska, so that it does not appear to reach the prairie region. There are ten species, of which those already published are regalis Dodge, chenopodii Brun., turnbulli Thom., and plagosus Scudd.

Bradynotes Scudder is confined to the extreme northwestern United States, and contains seven species, of which the only ones already described are hispida Brun., and obesa Thom. (opimus Scudd.).

Dendrotettix Riley has but a single and dimorphic species, quercus Ril. (longipennis Ril.), ranging from Missouri to Texas.

Podisma Latreille is used in replacement of Pezotettix Burmeister for reasons given in Psyche (vii, 195). It has a wider distribution than any other genus of Melanopli, being found in Europe and temperate Asia, as well as in America. The American species occur in two great districts, one in the west from Alberta to northern New Mexico, the other in the east from western Ontario and New York to Maine. There are eight American species, of which those already described are the following: glacialis Scudd., stupefacta Scudd., dodgei Thom., marshallii Thom., and oregonensis Thom. Eupodisma is a subgeneric term for primnoa Fisch. de W. of Siberia.

Paratylotropidia Brunner is based on an undescribed species found from Dakota to Texas.

Melanoplus Stål is the dominant genus, with one hundred and thirtyone species, but it is confined to North America. These species have been grouped into twenty-eight series, but as, on account of its pre-eminent importance, this genus is treated separately in another paper in press, no further account of the species is given here.

Phœtaliotes gen. nov. is based upon a single species, nebrascensis Thom., found in the western part of the Mississippi basin, and beyond its latitudinal limits from Alberta to Mexico.

Paroxya Scudder has three species, mostly confined to the Atlantic and Gulf States; they are atlantica Scudd., hoosieri Blatchl., and floridana Thom. 
Pœcilotettix gen. nov. is represented by three species: picticornis Thom., and two new species, found only on the Pacific coast near our southern borders.

Edaleonotus gen. nov. is based on the polymorphic species, collaris Scudd., found on the Pacific coast.

Asemoplus gen. nov. is based on a single species, montanus Brun., found in the extreme northwestern United States.

Philocleon gen. nov. has but a single species, nigrovittatus Stål, from Mexico.

Aptenopedes Scudder is known only from the Gulf States, with the three species, sphenarioides Scudd., rufovittata Scudd., and aptera Scudd. 


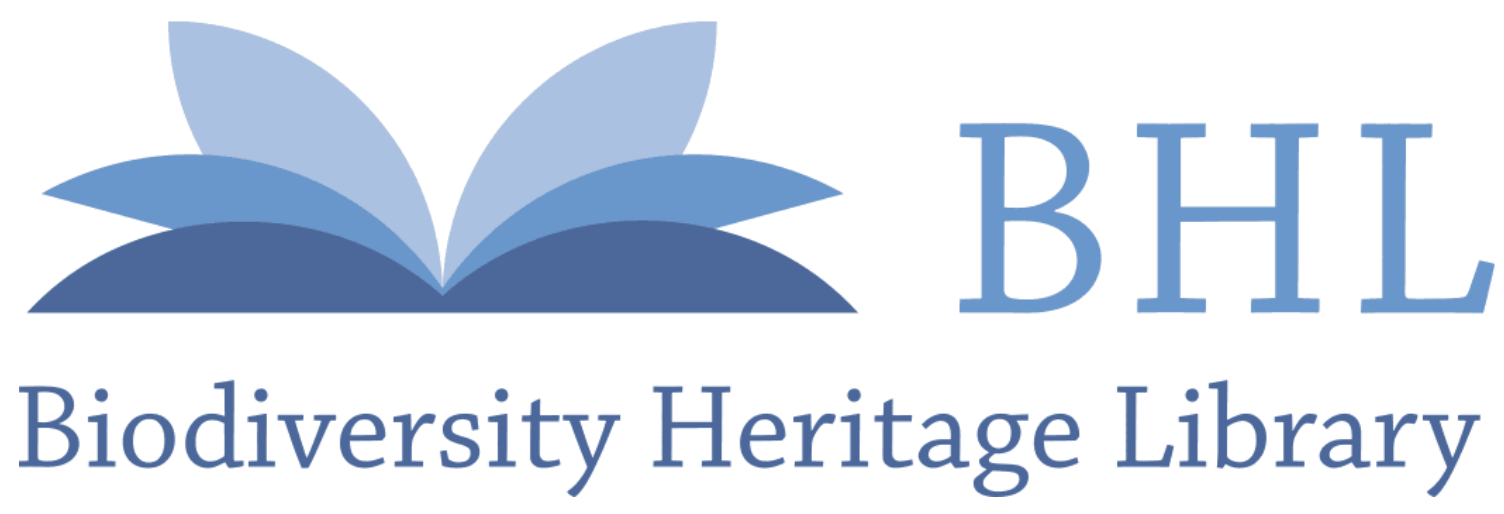

Scudder, Samuel Hubbard. 1897. "The Genera of North American Melanopli." Proceedings of the American Academy of Arts and Sciences 32, 195-206.

https://doi.org/10.2307/20020687.

View This Item Online: $\underline{\text { https://www.biodiversitylibrary.org/item/22280 }}$

DOI: https://doi.org/10.2307/20020687

Permalink: https://www.biodiversitylibrary.org/partpdf/145146

\section{Holding Institution}

MBLWHOI Library

Sponsored by

MBLWHOI Library

\section{Copyright \& Reuse}

Copyright Status: NOT_IN_COPYRIGHT

This document was created from content at the Biodiversity Heritage Library, the world's largest open access digital library for biodiversity literature and archives. Visit BHL at https://www.biodiversitylibrary.org. 